\title{
PEMBELAJARAN BERBASIS MASALAH UNTUK MENINGKATKAN KEMAMPUAN BERPIKIR KRITIS DAN KREATIF MATEMATIS SISWA SEKOLAH DASAR
}

\author{
Santy Widiani \\ STKIP Subang \\ santyw@gmail.com
}

\begin{abstract}
The ability to think critically and think creatively is very important and needs to be improved in mathematics learning. However, mathematical critical and creative thinking skills at the level of basic education have not been handled well as a result of the ability to think critically and students' creative thinking is low. Therefore, the teacher must determine the right learning so that it can facilitate students to improve students' thinking skills. One learning strategy that can be done is to apply problem-based learning. This research is a quasi-experimental research with the design used is "Nonequivalent Control Group Design". The sample in this study were the fifth grade students of Lembang Subdistrict, West Bandung Regency, from three schools, each with a high, medium and low level of six classes with three classes of experimental groups and three classes of control groups. Data were obtained from students 'mathematical critical and creative thinking tests, observation sheets, interviews, and questionnaires to determine students' responses to problem-based learning. The results showed that mathematics learning with problem-based learning can improve critical thinking skills and mathematical creative thinking of elementary school students. Mathematical learning with problem-based learning is significantly better in improving the mathematical and creative thinking skills of elementary school students compared to students who take learning with conventional strategies viewed from the school level and learning factors. In addition, most students showed a positive response to the learning that was done and found a correlation between students' test scores and student attitudes scale. Based on the results of the study, mathematics learning with problem-based learning can be used as an alternative learning that can be applied in an effort to improve students 'abilities, especially the students' critical and creative thinking skills.
\end{abstract}

Keywords: Problem Based Learning, Student Mathematical critical thinking ability, Student Mathematical Creative Thinking Ability.

\begin{abstract}
ABSTRAK
Kemampuan berpikir kritis dan berpikir kreatif merupakan hal yang sangat penting dan perlu ditingkatkan dalam pembelajaran matematika. Namun, kemampuan bepikir kritis dan kreatif matematik di tingkat pendidikan dasar belum tertangani dengan baik akibatnya kemampuan berpikir kritis dan
\end{abstract}


berpikir kreatif siswa rendah. Oleh karena itu, guru harus menentukan pembelajaran yang tepat sehingga dapat mempermudah siswa untuk meningkatkan kemampuan berpikir siswa. Salah satu strategi pembelajaran yang dapat dilakukan adalah dengan menerapkan pembelajaran berbasis masalah. Penelitian ini merupakan penelitian kuasi eksperimen dengan desain yang digunakan adalah "Nonequivalent Control Group Design". Sampel dalam penelitian ini adalah siswa kelas V SD Kecamatan Lembang Kabupaten Bandung Barat, dari tiga sekolah yang masing-masing berlevel tinggi, sedang, dan rendah sebanyak enam kelas dengan tiga kelas kelompok eksperimen dan tiga kelas kelompok kontrol. Data diperoleh dari tes kemampuan berpikir kritis dan kreatif matematik siswa, lembar observasi, wawancara, dan angket untuk mengetahui respon siswa mengenai pembelajaran berbasis masalah. Hasil penelitian menunjukkan bahwa pembelajaran matematika dengan pembelajaran berbasis masalah dapat meningkatkan kemampuan berpikir kritis dan berpikir kreatif matematik siswa sekolah dasar. Pembelajaran matematika dengan pembelajaran berbasis masalah secara signifikan lebih baik dalam meningkatkan kemampuan berpikir kritis dan kreatif matematik siswa sekolah dasar dibandingkan dengan siswa yang mengikuti pembelajaran dengan strategi konvensional ditinjau dari level sekolah dan faktor pembelajaran. Selain itu, sebagian besar siswa menunjukkan respon yang positif terhadap pembelajaran yang telah dilakukan serta ditemukan adanya korelasi antara skor tes siswa dengan skala sikap siswa. Berdasarkan hasil penelitian tersebut, maka pembelajaran matematika dengan pembelajaran berbasis masalah dapat dijadikan sebagai alternatif pembelajaran yang dapat diterapkan dalam upaya meningkatkan kemampuan siswa khususnya kemampuan berpikir kritis dan kreatif siswa.

Kata kunci: Pembelajaran Berbasis Masalah, Kemampuan berpikir kritis Matematik Siswa, Kemampuan Berpikir Kreatif Matematik Siswa.

\section{A. Pendahuluan}

Ilmu pengetahuan dan

teknologi sangat berperan dalam

upaya meningkatkan kualitas

sumber daya manusia bagi suatu

bangsa. Dengan adanya

peningkatan sumber daya manusia

diharapkan bangsa kita mampu

bersaing dengan bangsa-bangsa

lain. Salah satu upaya yang dapat dilakukan untuk meningkatkan sumber daya manusia adalah peningkatan mutu pendidikan. Upaya yang dapat dilakukan untuk meningkatkan mutu pendidikan adalah perbaikan proses pembelajaran. Dalam usaha perbaikan proses pembelajaran diperlukan sistem pendidikan yang berorientasi pada pemecahan 
masalah, kemampuan berpikir kritis, kreatif, sistematis, dan logis. Hal ini sangat mungkin dimunculkan dalam pembelajaran matematika, karena mengingat semua kemampuan tersebut merupakan bagian dari tujuan pembelajaran matematika (Depdiknas, 2003).

\section{Pemerintah}

melalui

Departemen Pendidikan Nasional (Depdiknas) dan Departemen Agama (Depag) telah melakukan berbagai usaha untuk meningkatkan mutu dan hasil pendidikan nasional, termasuk pendidikan matematika pada pendidikan dasar sampai pendidikan menengah. Usaha pemerintah dalam meningkatkan mutu dan hasil pendidikan nasional antara lain peningkatan kualitas guru melalui program profesi guru (PPG), merekonstruksi kurikulum sehingga muncul Kurikulum Berbasis Kompetensi (KBK) selanjutnya lahirlah Kurikulum Tingkat Satuan Pendidikan (KTSP). Dalam KTSP dijelaskan bahwa kecakapan atau kemahiran matematika yang diharapkan dalam pembelajaran matematika mencakup: (a) memahami konsep, (b) memiliki kemampuan berpikir logis, analitis, sistematis, kritis, dan kreatif serta mempunyai kemampuan bekerja sama, (c) memiliki kemampuan pemecahan masalah, (d) memiliki sikap menghargai matematika dan kegunaannya dalam kehidupan.

NCTM (2000) menyatakan bahwa standar kemampuan yang harus dicapai dalam pembelajaran matematika adalah penalaran matematis (mathematical reasoning), representasi matematis (mathematical representation), komunikasi matematis (mathematical communication), mengaitkan ideide matematis (mathematical connection), dan pemecahan masalah (mathematical problem solving). Bedasarkan tujuan tersebut, maka dalam proses pembelajaran matematika diperlukan sistem pendidikan yang berorientasi pada pemecahan masalah, kemampuan berpikir kritis, kreatif, sistematis, dan logis. keterampilan berpikir kritis dan 
kreatif merupakan hal yang penting dalam pembelajaran matematika, dan perlu dilatihkan pada siswa. Karena dengan keterampilan berpikir kritis dan kreatif diharapkan siswa mampu memecahkan permasalahan matematik yang menjadi fokus dalam pembelajaran matematika.

Di lain pihak, Dengan semakin pesatnya perkembangan ilmu pengetahuan dan teknologi, sehingga memberi kesempatan kepada siswa untuk semakin leluasa mengakses informasi. Untuk itu diperlukan kemampuan dalam cara mengakses sumber informasi, memilih dan memilah jenis dan tipe informasi. Kemampuan ini dapat diperoleh melalui pengembangan kemampuan berpikir kritis, logis, sistematis, analitis, kreatif, dan produktif (Kusumah, 2008). Berdasarkan alasan tersebut, kemampuan berpikir matematis tingkat tinggi (high-order mathematical thinking) khususnya berpikir kritis dan kreatif peserta didik sangat penting untuk dikembangkan dan dilatihkan pada siswa mulai dari jenjang pendidikan dasar sampai sekolah menengah atas.

Kenyataan di lapangan menunjukan bahwa hasil pembelajaran matematika terutama yang menuntut kemampuan berpikir kritis dan kreatif siswa di SD, SMP, dan SMA masih rendah. Kondisi ini ditunjukan oleh International Achievement Education (IEA) yang menyebutkan bahwa siswa SD di Indonesia menempati peringkat ke38 dari 39 negara peserta. Selain itu, data dari the Third International Mathematics and Science Study (TIMSS) tahun 2007 juga menunjukan bahwa Indonesia berada pada urutan ke 36 dari 48 negara. Berdasarkan hasil studi TIMSS dan IAE tampak bahwa untuk masalah matematika yang menuntut kemampuan berpikir tingkat tinggi, siswa Indonesia masih jauh di bawah rata-rata internasional. Kemampuan pemecahan masalah, kemampuan berpikir kritis, dan kreatif siswa di Indonesia masih rendah, sehingga 
siswa lemah dalam menyelesaikan masalah tidak rutin.

Rendahnya hasil belajar matematika mengindikasikan ada sesuatu yang salah dan belum optimal dalam pembelajaran matematika di sekolah. Menurut Herman salah satu penyebab rendahnya kualitas pemahaman siswa di SD dan SMP berdasarkan Hasil survey IMSTEP-JICA (1999): dalam proses pembelajaran matematika guru terlalu berkonsentrasi pada latihan soal dari pada mengembangkan pemahaman matematika siswa. Ruseffendi (1991:328) menyatakan bahwa selama ini dalam proses pembelajaran matematika di kelas pada umumnya siswa mempelajari matematika hanya diberi tahu oleh gurunya dan bukan melalui kegiatan esplorasi. Sumarmo (1993) menyatakan bahwa pembelajaran matematika pada umumnya kurang melibatkan aktivitas siswa secara optimal sehingga siswa kurang aktif dalam belajar. Pendekatan pembelajaran rutin seperti ini sering dilakukan oleh banyak guru dalam keseharian sehingga dapat membosankan, membahayakan, dan merusak seluruh minat siswa (Sobel dan Maletsky, 2003). Dengan demikian, kemungkinan besar pengembangan kemampuan berpikir kritis dan kreatif siswa dalam matematika pun akan terhambat. Akibatnya kemampuan siswa dalam berpikir matematis tingkat tinggi sangat lemah, karena siswa terbiasa dengan kegiatan pembelajaran yang hanya pada tataran berpikir tingkat rendah.

Menyikapi permasalahanpermasalahan yang timbul dalam pendidikan matematika sekolah, maka hendaknya ada suatu inovasi dalam pembelajaran yang dapat menjawab permasalahanpermasalahan dalam pendidikan matematika. Salah satu solusi yang dipandang dapat mengatasi masalah dalam pembelajaran matematika tersebut adalah dengan meningkatkan kualitas pembelajaran. Pembelajaran yang diperlukan adalah pembelajaran yang berpusat pada siswa dan memberikan kesempatan kepada siswa untuk meningkatkan 
kemampuan berpikir kritis dan kreatif. Salah satu model pembelajaran yang dapat merangsang kemampuan berpikir kritis dan kreatif dan memungkinkan terjadinya pertukaran ide secara terbuka adalah pembelajaran berbasis masalah (PBM). PBM merupakan suatu strategi yang dimulai dengan menghadapkan siswa pada masalah sehari-hari yang nyata atau masalah yang disimulasikan, sehingga siswa dituntut untuk berpikir kritis dan kreatif serta menempatkan siswa sebagai problem solver. Atas dasar permasalahan dan fakta-fakta yang diungkapkan di atas, penulis memiliki keinginan untuk mengembangkan pembelajaran berbasis masalah secara benar. Harapan dari pengembangan ini adalah bahwa dengan menggunakan pembelajaran berbasis masalah dapat mendorong peningkatan kemampuan berpikir kritis dan kreatif siswa SD dalam matematika.

\section{B. Kajian Pustaka}

\section{Berpikir Kritis}

Berpikir kritis banyak didefinisikan oleh para ahli dengan sudut pandang yang berbeda, Ennis (Hassoubah, 2004 : 85) menyatakan bahwa "berpikir kritis adalah berpikir secara beralasan dan reflektif dengan menekankan pada pembuatan keputusan tentang apa yang harus dipercayai atau dilakukan". Sejalan dengan itu Johnson (2007 : 185) mendefinisikan "berpikir kritis sebagai sebuah proses terorganisasi yang memungkinkan siswa mengevaluasi bukti, asumsi, logika, dan bahasa yang mendasari pernyataan orang lain". Ennis (Ismaimuza, $2010: 20$ ) berpendapat bahwa terdapat enam elemen dasar dalam berpikir kritis yang diakronimkan dalam FISCO, yaitu:

a. Fokus (Focus) terhadap situasi yang menggambarkan masalah utama, dalam hal ini kita dapat mengajukan pertanyaan: apa yang terjadi/diketahui, apa masalah yang sebenarnya, bagaimana membuktikannya. 
b. Alasan

(Reason)

memformulasikan argumentargumen yang menunjang kesimpulan, mencari bukti yang menunjang alasan dari suatu kesimpulan sehingga kesimpulan dapat diterima, mengidentifikasi, dan menjastifikasi masalah.

c. Inferensi (Inference), apakah alasan yang dikemukakan sudah tepat, bila ya, seberapa kuatkah alasan itu dapat mendukung kesimpulan yang dibuat.

d. Situasi (Situation), aktifitas berpikir juga dipengaruhi oleh lingkungan atau situasi yang ada di sekitar kita

e. Klasifikasi (Clarify), hal itu dapat dilakukan dengan menanyakan: apa maksudnya, dapatkah memberi contoh lain, dapatkah kamu mencarinya dengan cara lain.

f. Keseluruhan (Overview), mengecek kembali hasil yang didapatkan. Pada langkah ini diminta siswa untuk memeriksa kembali apa yang sudah ditemukan, diputuskan, dipertimbangkan, dijelaskan, dan kesimpulan yang diambil sudah benar atau masih terdapat kesalahan di dalamnya.

Menurut Mayer (Syukur, 2004:25) pengembangan kemampuan berpikir kritis harus didukung oleh lingkungan kelas yang mendorong munculnya diskusi tanya jawab, penyelidikan, dan pertimbangan. Lingkungan kelas yang demikian dapat dibuat melalui pengaturan kelas yang memungkinkan lebih banyak diskusi dan melalui pemberian pertanyaan-pertanyaan yang efektif dan jelas. Hal ini sejalan dengan yang dikemukakan oleh Zulfiani (2003:11) bahwa "untuk mengembangkan kemampuan berpikir kritis secara optimal diperlukan lingkungan kelas yang interaktif". Lebih lanjut Zulfiani mengemukakan bahwa syarat awal bagi terciptanya pembelajaran yang interaktif adalah pelajar harus tertarik kepada materi pembelajaran untuk kemudian terlibat aktif dalam proses pembelajaran. 
Untuk

menciptakan

lingkungan kelas yang dapat

membuat siswa aktif, guru harus mampu menciptakan suasana pembelajaran yang lebih diarahkan ke diskusi tanya jawab sehingga dapat terjadi interaksi sosial dan siswa dapat aktif mengemukakan pendapatnya. Hal tersebut dapat melatih proses kognitif siswa, sehingga kemampuan berpikir kritisnya dapat berkembang dengan baik.

\section{Berpikir Kreatif}

Para ahli mendefinisikan berpikir kreatif dari kata kreatifitas (Harris, 1998). Kreatifitas adalah kemampuan dan sikap seseorang untuk membuat produk yang baru (Fisher, 1995). Sedangkan menurut Evan (1991), kreatifitas adalah kemampuan untuk menemukan kaitan-kaitan yang baru, kemampuan melihat sesuatu dari perspektif (sudut pandang) yang baru, dan kemampuan untuk membentuk kombinasi-kombinasi dari banyak konsep yang ada pada pikiran. Kreatifitas bukanlah mengadakan sesuatu yang tidah ada menjadi ada, akan tetapi kreatifitas adalah kemampuan untuk menghasilkan ide-ide baru dengan cara membuat kombinasi, membuat perubahan, atau mengaplikasikan ide-ide yang ada pada wilayah yang berbeda.

Kemampuan berpikir kreatif dapat diukur dengan indikatorindikator yang telah ditentukan oleh para ahli. Adapun menurut Guilford (Hendrayana, 2008:19) indikator berpikir kreatif ada lima yaitu:

1. Kepekaan (problem sensitivity) adalah kemampuan mendeteksi (mengenali dan memahami) serta menanggapi suatu pernyataan, situasi, atau masalah.

2. Kelancaran (fluency) adalah kemampuan untuk menghasilkan banyak gagasan.

3. Keluwesan (flexibility) adalah kemampuan untuk mengemukakan bermacammacam pemecahan atau pendekatan terhadap masalah.

4. Keaslian (originality) adalah kemampuan untuk mencetuskan gagasan dengan cara-cara yang asli, tidak klise, 
dan jarang diberikan kebanyakan orang.

5. Elaborasi (elaboration) adalah kemampuan menambah suatu situasi atau masalah sehingga menjadi lengkap, dan merincinya secara detil, yang di dalamnya dapat berupa tabel, grafik, gambar, model dan katakata.

\section{Pembelajaran}

Berbasis

\section{Masalah}

Pembelajaran berbasis masalah (problem-based learning) merupakan pembelajaran yang menitikberatkan pada kegiatan pemecahan masalah, dan masalah yang diberikan adalah masalah yang belum jadi atau tidak terstruktur dengan baik (ill structured problem), sehingga dapat menantang siswa untuk berpikir dan melakukan diskusi secara berkelompok. Siswa dihadapkan pada masalah nyata atau masalah yang disimulasikan, siswa bekerja sama secara berkelompok untuk mengembangkan keterampilan memecahkan masalah (problem solving), kemudian siswa mendiskusikan apa yang harus dilakukan.

Menurut Barrows dan Kelson (Amir, 2009:21) menyatakan bahwa "PBM adalah kurikulum dan proses pembelajaran". Dalam kurikulumnya dirancang masalahmasalah yang menuntut siswa mendapatkan pengetahuan yang penting, membuat mereka mahir dalam memecahkan masalah, dan memiliki strategi belajar sendiri serta memiliki kecakapan berpartisipasi dalam kelompok. Proses pembelajarannya menggunakan pendekatan yang sistemik untuk memecahkan masalah atau menghadapi tantangan yang diperlukan dalam kehidupan sehari-sehari. Sejalan dengan itu Dutch (Taufik, 2009) mengungkapkan bahwa PBM merupakan metode instruksional yang menantang siswa agar "belajar untuk belajar", bekerja sama dalam kelompok untuk mencari solusi bagi masalah yang nyata. Lebih lanjut Dutch juga menyatakan bahwa PBM mempersiapkan siswa untuk berpikir kritis dan analitis, dan 
untuk mencari serta menggunakan sumber pembelajaran yang sesuai.

Proses pembelajaran seperti yang tersirat dalam pengertian pembelajaran berbasis masalah merupakan pembelajaran yang dilandasi oleh paham konstruktivisme yang menganut asumsi bahwa pemahaman muncul melalui interaksi dengan lingkungan, dan konflik kognitif adalah stimulus untuk belajar yang menentukan hakikat dari apa yang dipelajari (Savery dan Duffy dalam Hulu, 2009)

Pembelajaran berbasis masalah mempunyai karakteristik tertentu dibandingkan dengan pembelajaran yang lain. Cirri utama pembelajaran berbasis masalah menurut Slavin (dalam Juandi, 2006) meliputi pengajuan pertanyaan terhadap situasi atau masalah, berfokus pada keterkaitan antar disiplin, penyelidikan autentik, kerjasama, dan menghasilkan produk atau karya kemudian memamerkannya.

\section{Metode Penelitian}

Penelitian ini dilaksanakan dengan menggunakan metode penelitian kuasi eksperimen.

Karena dalam penelitian ini, subjek yang akan diteliti merupakan siswa-siswa yang sudah terdaftar dengan kelasnya masing-masing, sehingga tidak dimungkinkan untuk membuat kelompok baru secara acak. Pada penelitian ini peneliti tidak mengelompokan secara acak tetapi memilih dua kelompok secara acak sebagai subjek penelitian, yaitu kelompok eksperimen yang melakukan pembelajaran dengan menggunakan model pembelajaran berbasis masalah dan kelompok kontrol dengan melakukan pembelajaran konvensional.

Desain penelitian yang digunakan adalah Nonequivalent Control Group Design (Sugiono, 2009 : 116). Disain penelitian tersebut berbentuk:

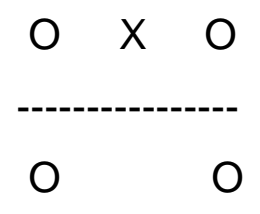

Pada desain ini, peneliti tidak mengelompokan secara acak 
namun sekolah dipilih secara acak dilanjutkan pemilihan kelas secara acak, yaitu kelas eksperimen dan kelas kontrol. Selanjutnya masingmasing kelas penelitian diberi pretes dan postes (O) dengan instrumen yang sama. Kelas eksperimen diberi perlakuan pembelajaran berbasis masalah (X) dan kelas kontrol mendapat pembelajaran konvensional tanpa perlakuan khusus.

Populasi pada penelitian ini adalah seluruh siswa kelas V SD di Kecamatan Lembang Kabupaten Bandung Barat. Pemilihan sampel dilakukan dengan menggolongkan terlebih dahulu sekolah dalam tiga level, yaitu sekolah dengan level tinggi, sedang, dan rendah berdasarkan data hasil ujian nasional (UASBN) selama tiga tahun terakhir. Dari data hasil observasi SDN di Kecamatan Lembang terdapat 63 sekolah, dari setiap level sekolah dipilih satu sekolah sehingga menjadi tiga sekolah Terpilih secara acak SDN pancasila yang mewakili sekolah level tinggi, SDN jayagiri I yang mewakili sekolah level sedang, dan SDN 10 lembang yang mewakili sekolah level rendah. Pada masing-masing level sekolah dipilih secara acak dua kelas yang memiliki kemampuan matematika yang relatif sama, satu kelas yang memperoleh pembelajaran berbasis masalah (kelas eksperimen) dan satu kelas lagi memperoleh pembelajaran konvensional (kelas kontrol)

D. Hasil Penelitian dan

\section{Pembahasan}

\section{Hasil Penelitian}

\section{a. Kemampuan berpikir kritis}

Untuk mengetahui pembelajaran mana yang lebih baik dalam kemampuan berpikir kritis matematik siswa sekaligus untuk menjawab hipotesis penelitian, dilakukan uji statistik lanjutan melalui uji-t yang dengan lengkap disajikan di lampiran. Hasil perhitungan terangkum pada Tabel 1 berikut.

\section{Tabel 1}

Hasil Uji-t Perbandingan

Kemampuan Berpikir Kritis antara Siswa Kelompok Eksperimen dan Kelompok Kontrol 


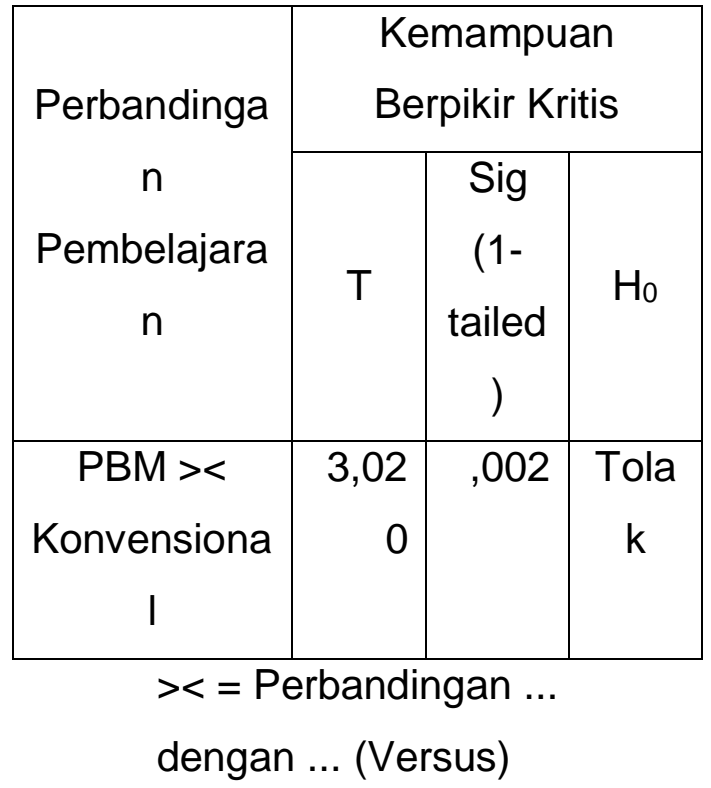

$\mathrm{H}_{0}$ : Tidak terdapat perbedaan peningkatan kemampuan berpikir kritis matematik siswa yang signifikan antara siswa yang mendapatkan pembelajaran berbasis masalah dengan siswa yang mendapatkan pembelajaran konvensional.

$\mathrm{H}_{1}$ : Peningkatan kemampuan berpikir kritis matematis yang memperoleh pembelajaran berbasis masalah secara signifikan lebih baik daripada kemampuan berpikir kritis matematis siswa yang mengikuti pembelajaran konvensional.

Tabel 4.1terlihat bahwa nilai signifikansinya adalah 0,002 atau kurang dari 0,05 sehingga $\mathrm{H}_{0}$ ditolak maka dapat disimpulkan bahwa peningkatan kemampuan berpikir kritis matematis yang memperoleh pembelajaran berbasis masalah secara signifikan lebih baik daripada kemampuan berpikir kritis matematis siswa yang mengikuti pembelajaran konvensional.

Selanjutnya untuk menjawab hipotesis penelitian yang kedua yaitu dilihat dari masing-masing level sekolah, kemampuan berpikir kritis matematik siswa ditinjau dari pembelajarannya, hasil analisis dirangkum pada Tabel 4.13.

Tabel 2

Hasil Uji-t Perbandingan Kemampuan Berpikir Kritis Berdasarkan Level Sekolah

\begin{tabular}{|c|c|r|r|r|}
\hline \multirow{2}{*}{$\begin{array}{c}\text { Leve } \\
\text { I }\end{array}$} & Perband & \multicolumn{3}{|c|}{ Kemampuan } \\
ingan & Pembel & & Sig & \\
\cline { 3 - 5 } olah & ajaran & $t$ & $\begin{array}{r}\text { Kerpit } \\
\text { tail }\end{array}$ & $\mathrm{H}_{0}$ \\
& & & ed $)$ & \\
\hline Ting & PBM $><$ & 6,0 &, 00 & Tol \\
gi & Konvens & 17 & 0 & ak \\
& ional & & & \\
\hline Sed & PBM $><$ & 4,2 &, 00 & Tol \\
ang & Konvens & 76 & 0 & ak \\
& ional & & & \\
\hline
\end{tabular}




\begin{tabular}{|c|c|r|r|c|}
\hline $\begin{array}{c}\text { Ren } \\
\text { dah }\end{array}$ & $\begin{array}{c}\text { PBM }>< \\
\text { Konvens } \\
\text { ional }\end{array}$ & 3,0 &, 00 & Tol \\
& 20 & 2 & ak \\
\hline
\end{tabular}

Dari Tabel 4.2 di atas dapat dilihat bahwa nilai signifikansi untuk kelompok kemampuan berpikir kritis level tinggi, sedang, dan rendah berturut sebesar 0,000, 0,000, dan 0,002. Nilai signifikansi ini kurang dari 0,05, sehingga dapat disimpulkan bahwa peningkatan kemampuan berpikir kritis matematis yang memperoleh pembelajaran berbasis masalah secara signifikan lebih baik daripada kemampuan berpikir kritis matematis siswa yang mengikuti pembelajaran konvensional bagi siswa level sekolah tinggi, sedang, dan rendah.

Berdasarkan Tabel 4.1 dan Tabel 4.2 nampak bahwa peningkatan kemampuan berpikir kritis matematik siswa yang mendapat pembelajaran dengan menggunakan pembelajaran berbasis masalah secara signifikan lebih baik daripada kemampuan berpikir kritis matematik siswa yang mengikuti pembelajaran konvensional ditinjau dari pembelajaran dan level sekolah (tinggi, sedang, dan rendah).

\section{b. Kemampuan Berpikir Kreatif}

Untuk mengetahui pembelajaran mana yang lebih baik dalam kemampuan berpikir kreatif matematik siswa sekaligus untuk menguji hipotesis penelitian, dilakukan uji statistik lanjutan melalui uji-t yang dengan lengkap disajikan di lampiran. Hasil perhitungan terangkum pada Tabel 3 berikut.

Tabel 3

Hasil Uji-t Perbandingan

Kemampuan Berpikir Kreatif antara Siswa Kelompok Eksperimen dan Kelompok Kontrol

\begin{tabular}{|c|c|c|c|}
\hline \multirow{2}{*}{$\begin{array}{c}\text { Perbandinga } \\
n \\
\text { Pembelajara } \\
n\end{array}$} & \multicolumn{3}{|c|}{$\begin{array}{c}\text { Kemampuan } \\
\text { Berpikir Kreatif }\end{array}$} \\
\hline & $\mathrm{T}$ & $\begin{array}{c}\text { Sig } \\
(1- \\
\text { tailed }\end{array}$ & $\mathrm{H}_{0}$ \\
\hline $\begin{array}{c}\text { PBM }>< \\
\text { Konvensiona } \\
\text { | }\end{array}$ & $\begin{array}{r}5,43 \\
2\end{array}$ & ,000 & $\begin{array}{c}\text { Tola } \\
\mathrm{k}\end{array}$ \\
\hline
\end{tabular}

$><=$ Perbandingan ...

dengan ... (Versus) 
$\mathrm{H}_{0}$ : Tidak terdapat perbedaan peningkatan kemampuan berpikir kreatif matematik siswa yang signifikan antara siswa yang mendapatkan pembelajaran berbasis masalah dengan siswa yang mendapatkan pembelajaran konvensional.

$\mathrm{H}_{1}$ : Peningkatan kemampuan berpikir kreatif matematis yang memperoleh pembelajaran berbasis masalah secara signifikan lebih baik daripada kemampuan berpikir kreatif matematis siswa yang mengikuti pembelajaran konvensional.

Kriteria pengujian dengan menggunakan software SPSS 16.0 for windows berdasarkan taraf signifikansi 5\% adalah (Uyanto, 2006:36):

$\mathrm{H}_{0}$ : diterima jika nilai signifikasi $\geq$ 0,05

$\mathrm{H}_{0}$ : ditolak jika nilai signifikasi < 0,05

Tabel 3 terlihat bahwa nilai signifikansinya adalah 0,000 atau kurang dari 0,05 sehingga $\mathrm{H}_{0}$ ditolak. Dengan demikian dapat disimpulkan bahwa peningkatan kemampuan berpikir kreatif matematis yang memperoleh pembelajaran berbasis masalah secara signifikan lebih baik daripada kemampuan berpikir kreatif matematis siswa yang mengikuti pembelajaran konvensional.

Selanjutnya untuk menjawab hipotesis penelitian yang keempat yaitu dilihat dari masing-masing level sekolah, kemampuan berpikir kreatif matematik siswa ditinjau dari pembelajarannya, hasil analisis dirangkum pada Tabel 4.27.

\section{Tabel 4}

Hasil Uji-t Perbandingan

Kemampuan Berpikir Kreatif

Berdasarkan Level Sekolah

\begin{tabular}{|c|c|c|c|c|}
\hline \multirow[b]{2}{*}{$\begin{array}{l}\text { Leve } \\
\text { I } \\
\text { Sek } \\
\text { olah }\end{array}$} & \multirow[b]{2}{*}{$\begin{array}{l}\text { Perband } \\
\text { ingan } \\
\text { Pembel } \\
\text { ajaran }\end{array}$} & \multicolumn{3}{|c|}{$\begin{array}{l}\text { Kemampuan } \\
\text { Berpikir Kreatif }\end{array}$} \\
\hline & & $\mathrm{t}$ & $\begin{array}{l}\text { Sig } \\
(1- \\
\text { tail } \\
\text { ed) }\end{array}$ & $\mathrm{H}_{0}$ \\
\hline $\begin{array}{c}\text { Ting } \\
\text { gi }\end{array}$ & $\begin{array}{c}\text { PBM >< } \\
\text { Konvens } \\
\text { ional }\end{array}$ & $\begin{array}{r}3,6 \\
54\end{array}$ & $\begin{array}{r}, 00 \\
0\end{array}$ & $\begin{array}{l}\text { Tol } \\
\text { ak }\end{array}$ \\
\hline $\begin{array}{l}\text { Sed } \\
\text { ang }\end{array}$ & $\begin{array}{c}\text { PBM >< } \\
\text { Konvens } \\
\text { ional }\end{array}$ & $\begin{array}{r}3,2 \\
27\end{array}$ & $\begin{array}{r}, 00 \\
1\end{array}$ & $\begin{array}{l}\text { Tol } \\
\text { ak }\end{array}$ \\
\hline $\begin{array}{l}\text { Ren } \\
\text { dah }\end{array}$ & $\begin{array}{c}\text { PBM >< } \\
\text { Konvens } \\
\text { ional }\end{array}$ & $\begin{array}{r}2,6 \\
52\end{array}$ & $\begin{array}{r}, 00 \\
5\end{array}$ & $\begin{array}{l}\text { Tol } \\
\text { ak }\end{array}$ \\
\hline
\end{tabular}

Tabel 4 di atas dapat dilihat bahwa nilai signifikansi untuk 
kelompok kemampuan berpikir kreatif level tinggi, sedang, dan rendah berturut sebesar 0,000, 0,001 , dan 0,005. Nilai signifikansi ini kurang dari 0,05, sehingga dapat disimpulkan bahwa peningkatan kemampuan berpikir kreatif matematis yang memperoleh pembelajaran berbasis masalah secara signifikan lebih baik daripada kemampuan berpikir kreatif matematis siswa yang mengikuti pembelajaran konvensional bagi siswa level sekolah tinggi, sedang, dan rendah.

Berdasarkan Tabel 3 dan Tabel 4 nampak bahwa peningkatan kemampuan berpikir kreatif matematik siswa yang mendapat pembelajaran dengan menggunakan pembelajaran berbasis masalah secara signifikan lebih baik daripada kemampuan berpikir kreatif matematik siswa yang mengikuti pembelajaran konvensional ditinjau dari pembelajaran dan level sekolah (tinggi, sedang, dan rendah).
2. Pembahasan

a. Pembelajaran

berbasis masalah

Hasil penelitian ini menunjukkan bahwa pembelajaran berbasis masalah efektif untuk meningkatkan kemampuan berpikir kritis dan kemampuan komunikasi matematis siswa. Ketika pemecahan masalah digunakan sebagai konteks dalam matematika, fokus kegiatan belajar sepenuhnya berada pada siswa yaitu berpikir menemukan solusi dari suatu masalah matematika termasuk proses untuk memahami suatu konsep dan prosedur matematika yang terkandung dalam masalah tersebut. Menurut Herman (2006) kondisi seperti ini telah memicu terjadinya konflik kognitif sebagai akibat dari masalah yang diberikan kepada siswa. Dalam situasi konflik kognitif, siswa akan memanfaatkan kemampuan kognitifnya dalam upaya-upaya mencari justifikasi dan konfirmasi terhadap pengetahuan yang ada dalam pikirannya. Melalui aktivitas mental seperti ini, kemampuan kognitif 
siswa mendapat kesempatan

untuk diberdayakan dan dimantapkan. Dengan demikian dapat dipahami bahwa dalam pembelajaran berbasis masalah siswa telah berupaya secara maksimum menggunakan segenap kemampuan yang dimiliki. Jadi pembelajaran dengan model pembelajaran berbasis masalah dibandingkan dengan pembelajaran biasa, menunjukkan pengaruh yang signifikan terhadap peningkatan kemampuan berpikir kritis dan kemampuan komunikasi matematis siswa.

Telah dikemukakan sebelumnya bahwa salah satu langkah dalam pembelajaran berbasis masalah adalah pengorganisasian siswa dalam kelompok belajar. Peran guru sebagai fasilitator dan organisator tidaklah semudah yang dibayangkan. Agar pembelajaran dapat berjalan dengan efektif, guru perlu membuat perencanaan yang matang, terutama menyangkut bahan ajar dan bentuk bantuan yang diberikan kepada siswa jika mengalami kesulitan dalam pemecahan masalah. Dalam pembelajaran kelompok, guru tidaklah sekadar mengelompokkan siswa ke dalam beberapa kelompok belajar. Namun hal yang penting dilakukan guru adalah mendorong agar setiap siswa dapat berpartisipasi dan berinteraksi sepenuhnya dalam aktivitas belajar. Karena interaksi yang maksimal dalam kelompok sangat menentukan keberhasilan dalam penyelesaian masalah.

Dari paparan di atas kiranya dapat dipahami bahwa keberhasilan pembelajaran berbasis masalah sangat ditentukan oleh sajian masalah yang diberikan kepada siswa, bantuan guru secara tepat dan tidak langsung ketika siswa mengalami kendala, dan interaksi siswa dalam proses pembelajaran. Oleh karena itu, masalah yang disajikan kepada siswa janganlah masalah yang tidak bisa dijangkau oleh siswa. Diusahakan masalah tersebut tidak terlalu mudah dan tidak terlalu sulit. Dengan kata lain masalah yang disajikan terjangkau oleh kemampuan siswa. Masalah 
yang disajikan selanjutnya harus menarik dan menantang. Hal ini dimaksudkan agar siswa mempunyai keinginan dan motivasi untuk menyelesaikan masalah tersebut. Selain itu diusahakan intervensi guru harus minimal dan diberikan ketika siswa memang benar-benar membutuhkan serta diusahakan interaksi dalam kelompok berjalan dengan efektif. Tidak bisa dipungkiri dalam proses pembelajaran berbasis masalah suatu kesulitan yang akan dialami oleh guru manakala banyak kelompok mengalami kendala dalam menyelesaikan masalah. Upaya yang dapat dilakukan guru adalah dengan memberdayakan siswa dalam bekerja sama untuk berinteraksi dalam kelompok secara maksimal. Oleh karena itu, interaksi multi arah selama proses pemecahan masalah menjadi suatu kekuatan dari pembelajaran berbasis masalah.

\section{b. Level sekolah}

Hasil penelitian menunjukan bahwa faktor pembelajaran tidak berinteraksi secara signifikan dengan faktor level sekolah dalam kemampuan berpikir kritis dan kreatif. Temuan ini menunjukan bahwa pembelajaran dengan pendekatan berbasis masalah relatif sesuai untuk mengembangkan kemampuan berpikir kritis dan kreatif pada semua level sekolah

Berdasarkan tabel 4.8 dan tabel 4.22 menunjukan bahwa siswa yang berasal dari sekolah level tinggi menunjukan peningkatan kemampuan berpikir kritis dan kreatif lebih baik daripada siswa dari sekolah level rendah atau siswa dengan kemampuan matematika kurang. Dari temuan ini, ada beberapa alasan yang dapat dikemukakan. Alasan yang pertama adalah pada level sekolah rendah, raw inputnya pada umumnya siswa dengan kemampuan yang lebih rendah daripada siswa yang diterima di sekolah level sedang dan tinggi. Hal ini menunjukan bahwa siswa yang memiliki kemampuan awal baik, mengalami peningkatan kemampuan berpikir matematis lebih baik dibanding mereka yang kemampuan awalnya kurang. 
Banyaknya siswa yang mempunyai kemampuan matematika yang lebih baik sangat membantu efektifitas suatu kegiatan belajar mengajar karena membuat siswa lebih banyak mempunyai sumber belajar yang berasal dari siswa pandai. Hal ini sejalan dengan Harsunarko (MKPBM, 2001) siswa yang lebih pandai itu bisa menjadi tutor sebaya bagi teman yang lain. Berdasarkan hasi penelitian ini menunjukan bahwa perkembangan aktual mental siswa turut berperan dalam meningkatkan kemampuan berpikir kritis dan kreatif matematis siswa.

Berdasarkan temuan di atas, maka intervensi yang dilakukan guru cenderung berbeda antara satu sekolah dengan sekolah lainnya. Untuk sekolah level tinggi, intervensi yang dilakukan cenderung minimal, sedangkan sekolah dengan level sedang dan rendah berlaku sebaliknya. Dengan demikian, setiap siswa memperoleh intervensi guru secara proporsional sesuai dengan tahapan perkembangan actual dan potensinya masing-masing. Selain itu juga permasalahan yang disajikan dalam pembelajaran harus disesuaikan dengan kemampuan siswa.

\section{E. Kesimpulan}

1. Peningkatan kemampuan berpikir kritis matematis siswa yang memperoleh pembelajaran berbasis masalah secara signifikan lebih baik daripada kemampuan berpikir kritis matematis siswa yang mengikuti pembelajaran konvensional.

2. Peningkatan kemampuan berpikir kritis matematis siswa yang memperoleh pembelajaran berbasis masalah secara signifikan lebih baik daripada kemampuan berpikir kritis matematis siswa yang mengikuti pembelajaran konvensional ditinjau dari level sekolah.

3. Peningkatan kemampuan berpikir kreatif matematis siswa yang memperoleh pembelajaran berbasis masalah secara signifikan lebih baik daripada kemampuan berpikir kreatif matematis siswa yang mengikuti pembelajaran konvensional. 
4. Peningkatan

kemampuan

berpikir kreatif matematis siswa

yang memperoleh pembelajaran

berbasis masalah secara

signifikan lebih baik daripada

kemampuan berpikir kreatif

matematis siswa yang mengikuti

pembelajaran konvensional

ditinjau dari level sekolah.

5. Sikap siswa terhadap pembelajaran matematika dengan model pembelajaran berbasis masalah menunjukkan respon yang positif. Dengan kata lain, pembelajaran matematika berbasis masalah dapat meningkatkan sikap positif terhadap matematika. Secara lebih spesifik, terdapat korelasi antara hasil belajar siswa dengan sikap siswa terhadap pembelajaran matematika secara umum dan sikap siswa terhadap pembelajaran matematika berbasis masalah

\section{DAFTAR PUSTAKA}

Amir, M.T. (2009). Inovasi Pendidikan Melalui Problem Based Learning. Jakarta: Kencana Prenada Media Group
Arikunto, S. (2001). Dasar-dasar Evaluasi Pendidikan, (Edisi Revisi). Jakarta: Bumi Aksara

Departemen Pendidikan Nasional. (2003). Kurikulum standar kompetensi matematika sekolah menengah pertama dan madrasah tsanawiyah. Jakarta: Depdiknas

Evans, J.R. (1991), Creative Thinking in The Decision and Management Science. USA: South-Western Publishing Co

Fisher, R. (1995). Thinking Children to Think. Cheltenham, United-Kingdom: Staley Thornes Ltd

Fogarty, R. (1997). Problem-Based Learning and The Other Curriculum Models For Multiple Intelegences Classroom. Hawker Brownlow Education

Glazer, E. (2001). Using Web Sources to Promote Critical Thinking in High School. Tersedia http://math.unipa.

Hassoubah, Z.I. (2004). Developing Creative \& Critical Thinking Skills. Bandung: Nuansa

Hastuti, (2004).Analisis Kemampuan Berpikir Kritis Siswa SLTP pada Pembelajaran Matematika dengan Menggunakan Pendekatan Realistik.Skripsi matematika UPI:tidak diterbitkan

Hendrayana, A. (2008). Pengembangan Multimedia Interaktif untuk Meningkatkan Kemampuan Berpikir Kritis dan Kreatif Siswa SMP Dalam Matematik. Tesis PPS-UPI Bandung. Tidak Dipublikasikan Herman, T. (2005). Pembelajaran Berbasis Masalah Untuk 
Meningkatkan Kemampuan

Berpikir Matematika Tingkat

Tinggi Siswa Sekolah

Menengah Pertama (SMP).

Disertasi PPS-UPI Bandung.

Tidak dipublikasikan

Hudojo, H. (1998). Pemecahan

Masalah Dalam Matematika.

Jakarta: Depdiknas P3G.

Hulu. (2009). Pembelajaran

Berbasis Masalah untuk

Meningkatkan Kemampuan

Penalaran Matematika Siswa.

Tesis UPI Bandung. Tidak

Diterbitkan.

Ismaimusa. (2010). Meningkatkan

Kemampuan Berpikir Kritis dan

Kreatif Siswa Melalui

Pembelajaran Berbasis

Masalah dengan Strategi

Konflik Kognitif. Desertasi

PPS-UPI Bandung. Tidak

Dipublikasikan

Johnson. E. B. (2006). Contextual

Teaching and Learning.

California: Corwin Press.inc

Kusumah, Y.S. (2008). Desain dan

Pengembangan Computer

Based E-Learning Untuk

Meningkatkan High-Order

Mathematical Thinking Siswa

SMA. Laporan Penelitian

Hibah Bersaing Nasional 2008

(Tahap I). Jakarta: DP2M,

Dikti- Depdiknas

LTSIN. (2004). Learning Thinking.

Scotland: Learning and

Teaching Scotland

Maulana. (2007). Alternatif

Pembelajaran Matematika

dengan Pendekatan

Metakognitif utnuk

Meningkatkan Kemampuan

Berpikir kritis Mahasiswa

PGSD. Tesis SPs UPI

Bandung: tidak diterbitkan.
Mullis dkk. (2004) TIMSS: Trends in Mathematics And Science Study: Assessment Framework and Specification 2003.

Boston: The International Study Center.

Munandar. (1999). Belajar dan Membelajarkan. Jakarta: CV Rajawali

NCTM. (2000). Definiting Problem Solving. [Online]. Tersedia: http://www.learner.org/channel/ courses/teachingmath/gradesk _2/session_03/

section_03_a.html. (10 maret 2005)

Ratnaningsih, N. (2007). Pengaruh Pembelajaran Kontekstual

Terhadap Kemampuan

Berpikir Kritis dan Kreatif Matematik serta Kemandirian Belajar Siswa Sekolah Menengah Atas. Disertasi SPS-UPI Bandung. Tidak diterbitkan

Rohayati, A. (2005). Mengembangkan Kemampuan Berpikir Kritis Siswa dalam Matematika Melalui Pembelajaran dengan Pendekatan Kontekstual. Tesis SPs UPI Bandung: tidak diterbitkan.

Ruseffendi, E.T. (1998). Statistika Dasar Untuk Penelitian Pendidikan. Bandung: IKIP Bandung Press

Ruseffendi, E. T. (2005). DasarDasar Penelitian Pendidikan dan Bidang Non-Eksakta Lainnya. Bandung: Tarsito

Sugiono, (2009). Metode Penelitian Pendekatan Kualitatif, Kuantitatif, dan R\&D. Bandung: Alfabeta

Sumarmo, U. (1993). Peranan Kemampuan Logika dan 
Kegiatan Belajar Terhadap Kemampuan Pemecahan Masalah pada Siswa SMA di Kodya Bandung. Laporan Penelitian FPMIPA IKIP Bandung

Suryadi, D. (2005). Penggunaan Pendekatan Pembelajaran Tidak Langsung serta Pendekatan Gabungan Langsung dan Tidak Langsung dalam Rangka Meningkatkan Kemampuan Berpikir Matematis Tingkat Tinggi Siswa SLTP. Disertasi PPSUPI Bandung. Tidak dipublikasikan

Syukur, M. (2004). Pengembangan Kemampuan Berpikir Kritis Siswa SMU Melalui Pembelajaran dengan Pendekatan Open-Ended. Tesis PPS-UPI Bandung. Tidak Dipublikasikan

Tarwin, Y.W.(2005). Upaya Meningkatkan Kemampuan Berpikir Kritis Siswa Melalui Pendekatan Open-Ended dalam Pembelajaran Matematika. Skripsi. FPMIPA UPI

TIMSS. (1999). International Students Achievement In Mathematics.

http://timss:bc.edu/timss1999i/ pdf/t99i math 01.pdf

Wahyudin. (1999). Kemampuan Guru Matematika, Calon Guru Matematika, dan Siswa dalam Pelajaran Matematika. Disertasi PPS-UPI Bandung. Tidak dipublikasikan

Zulfiani. (2003). Model Pembelajaran Teknologi DNA Untuk Meningkatkan Keterampilan Berpikir Kritis
Siswa. Tesis. PPS UPI Bandung. 